\title{
Designing of an Open Innovation Model in Science and Technology Parks
}

Pari Bayat ( $\triangle$ paribayat95@gmail.com )

Islamic Azad University of Khorramabad https://orcid.org/0000-0003-3316-8232

Mehry Daraei

Islamic Azad University of Khorramabad

Amin Rahimikia

Islamic Azad University of Khorramabad

\section{Research}

Keywords: Science and Technology Park, Open Innovation Model, Grounded Theory, Factor Analysis

Posted Date: May 4th, 2021

DOl: https://doi.org/10.21203/rs.3.rs-482411/v1

License: (1) This work is licensed under a Creative Commons Attribution 4.0 International License.

Read Full License

Version of Record: A version of this preprint was published at Journal of Innovation and Entrepreneurship on January 25th, 2022. See the published version at https://doi.org/10.1186/s13731-022-00203-w. 


\section{Abstract}

The main purpose of this research is to design and test an open innovation model in science and technology parks through a mixed exploratory approach. The data collection tool in the qualitative section is a semi-structured interview with 15 experts in the field of science and technology parks. Purposive sampling was used until theoretical saturation is achieved. The grounded theory was used to coding the interviews. As a result of open, axial, and selective coding in MAXQDA, 1551 free codes, 202 concepts, 73 sub-codes, and 21 main codes extracted. These codes categorized in six themes of casual conditions, central factors, strategies, contextual conditions, confounding, and outcomes. Initial questionnaire was administrated among 516 experts and managers of science and technology parks in Tehran province and affiliated companies. Confirmatory factor analyses showed high model fit with CFI equal to 0.93 and high internal consistency for the total score equal to 0.98 . The results of this study showed that the proposed model of open innovation in science and technology parks in Iran has a good fit.

\section{Full-text}

Due to technical limitations, full-text HTML conversion of this manuscript could not be completed. However, the manuscript can be downloaded and accessed as a PDF.

\section{Figures}




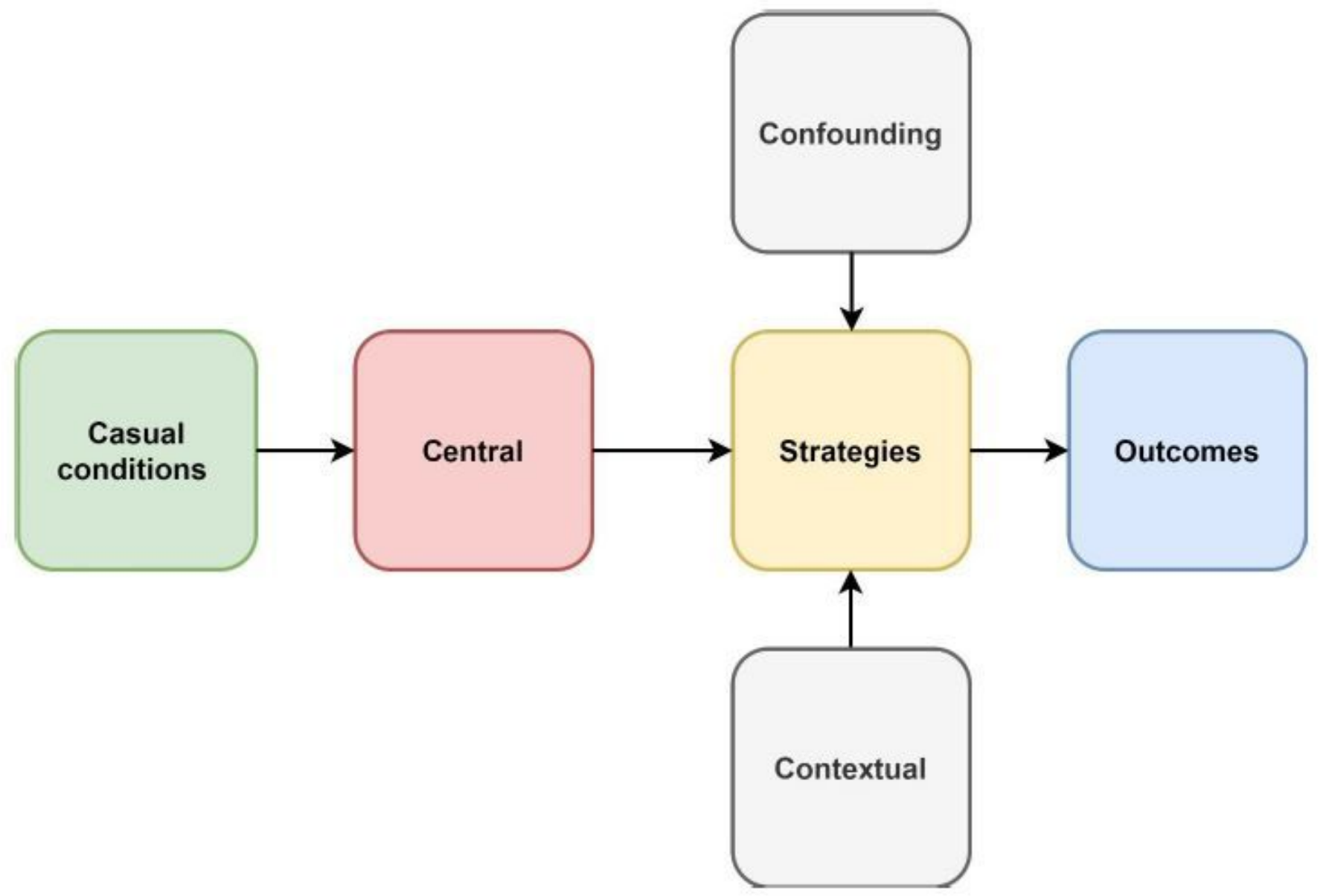

Figure 1

Conceptual model of open innovation in science and technology parks 